\section{THE HOUSTONS BANDING DYNAMOS, RETIRE PERMIT 00460}

Ron Jensen

1027 King Crescent

Saskatoon, SK S7K 0N9

Mary and Stuart Houston after 63 and 75 years of banding, respectively - have retired Stuart's banding permit obtained in 1943. The backstory and selected Saskatchewan banding history follows.

As a boy growing up in Yorkton, Saskatchewan, Stuart — at age 12 - was given a copy of Taverner's The Birds of Canada by two aunts ${ }^{1}$. He put Canada's leading bird book to good use identifying local birds. One day, however, Stuart observed a group of birds feeding on dandelions that weren't readily found among the illustrations in his book. Stuart's father advised him to visit Isabel Priestly, who helped to identify the birds as American Goldfinches.

Mrs. Priestly had come to Canada as a war bride in 1918, settling at Yorkton in 1935. A trained botanist, previously active in Winnipeg with the Manitoba Natural History Society, Mrs. Priestly invited Stuart and a few friends to join her on her weekly walks around Yorkton. She wrote a weekly nature column in the Yorkton Enterprise. Bird records collected during the weekly hikes, plus historical records from John Gunn and Frank Baines, who respectively resided at Good Spirit and Crescent Lakes, were compiled in July 1942 into a five-

page List of the Birds Identified in the Yorkton District in Recent Years, typed and mimeographed by Stuart Houston and which was priced at 10 cents.

Because R.J. Priestly was the Sifton Press representative in Yorkton, a rave review by A.G. Lawrence in Chickadee Notes, Winnipeg Free Press, was quickly reprinted in the Saskatoon Star-Phoenix and the Regina LeaderPost. Over 100 orders flooded in and many included bird observations from their locality. This quickly led to the creation of the Yorkton Natural History Society, which included four high school students: Harvey Beck, Stuart Houston, Vernon Barnes and Ray Adams. Stuart, as secretary-treasurer, kept track of membership, typed stencils for and mimeographed the quarterly bulletin, The Blue Jay, on a primitive open-drum copying machine. Student members hand-coloured the stencilled letterhead, The Blue Jay, in blue crayon for the first two years. Stuart's life as a naturalist had begun in Grade 9!

Due to the war effort, biologists

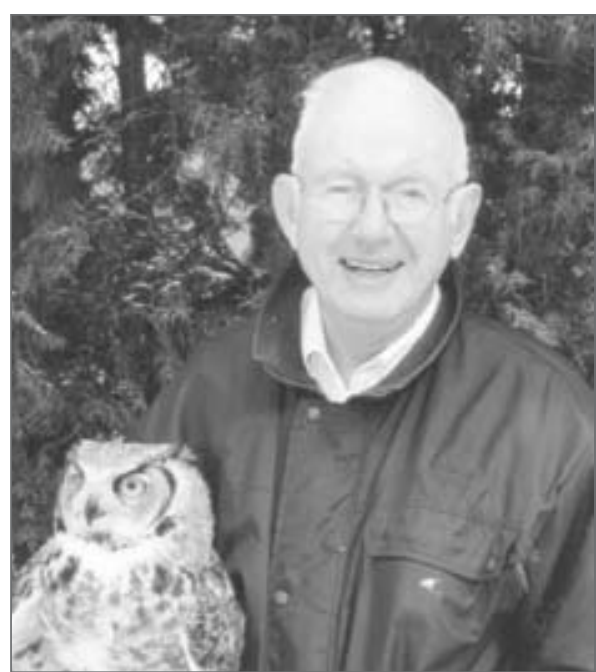

Stuart Houston holding a Great Horned Owl. Photo credit: Glen Grambo

for banding waterfowl were in short supply. Stuart, at 15 years in July of 1943, was approached by B. W. Cartwright, chief naturalist for Ducks Unlimited Canada (DUC) to band ducks. On the advice of Hoyes Lloyd of the Canadian Wildlife Service in Ottawa, Stuart omitted his age on the banding permit application. One had to be 18 to obtain a banding permit. The ducks were banded under Ducks Unlimited 00077 permit, and other species under Stuart's 00460 private permit, for a record 75 years of banding. At an American Ornithologist's Union (AOU) meeting in the 1960s, the head of the USA Bird Banding Laboratory (BBL), Allen Duvall, sought out Stuart and "volunteered that this was the only time during his tenure at the banding office that the U.S. FWS knowingly concurred in the issue of an under-age permit." 2

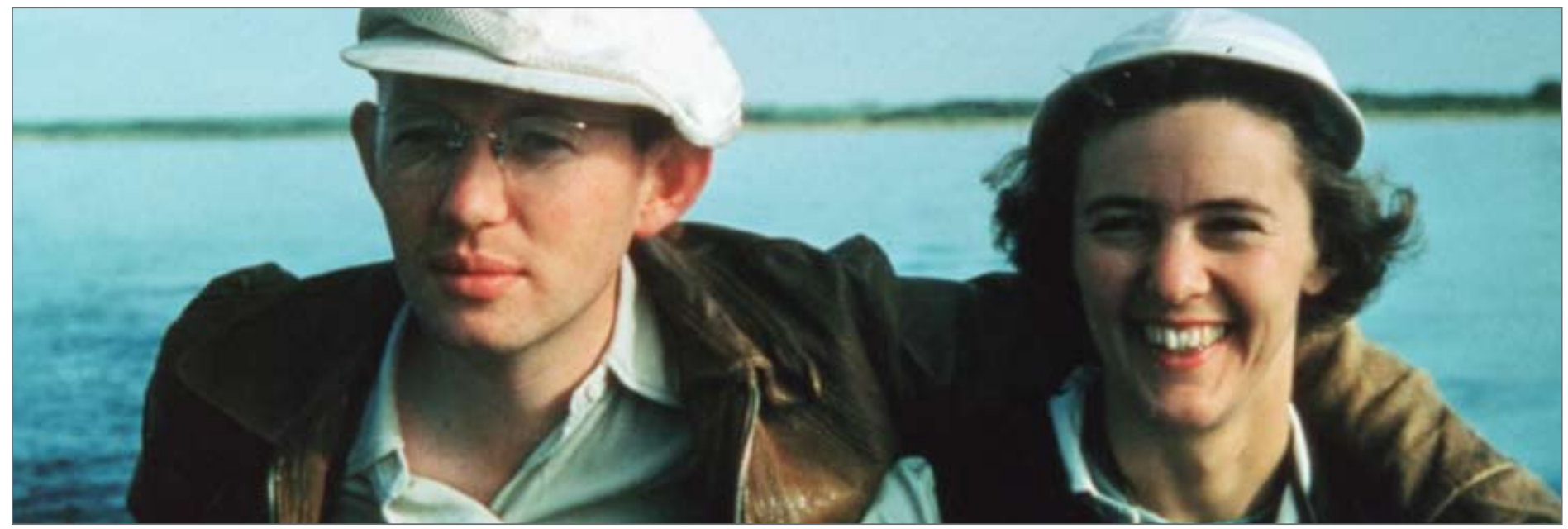


The first ringing (a British term for banding) by Stuart was in 1943, when he banded 556 ducks in 31 days, for which he was paid 10 cents a duck. ${ }^{3}$ The third year, over 2,100 ducks were banded in three months at 20 cents per duck, which yielded $\$ 427$, big money for a teenager. The year-round exciting recoveries arriving in the mail from Puerto Rico, Jamaica and $\mathrm{Cuba}^{3}$ after the first brief season were more important than money. Blue-winged Teal were shot on almost every Caribbean island.

In 1945, DUC offered Stuart a University scholarship to study wildlife management at the University of Wisconsin under Aldo Leopold, or ornithology at Cornell University under Arthur Allen. Stuart declined, saying, "If I take that offer, what would I do for a hobby?" 3 He was accepted into medicine and graduated with an MD from the University of Manitoba — his parents' alma mater - in 1951; that year, Stuart married Mary Belcher, a teacher at Yorkton Collegiate, and he joined his parents' medical practice for nine years.

A 53-page booklet summarized results from the banding of 63,826 waterfowl by DUC between 1939 and 1950 , and 22,270 were banded in Saskatchewan. Stuart's contribution to the total number banded was 5,011. ${ }^{4}$ Banding was now both a hobby and an obsession.

Seth Low of the U.S. Fish \& Wildlife Service, Chief of the BBL in Patuxent, Maryland, brought two mist nets - a new technology and at his own expense - to Stuart and Mary in Yorkton on August 19, 1954, instructing them on set-up and use of the mist nets along a road allowance. They quickly caught one Gray Catbird and one Yellow Warbler. While dawn mist netting for Wilson's Snipe on September 20, 1961, a Pectoral Sandpiper was caught and that sandpiper was shot on May 28, 1963, near Yanskiy, Yakut, U.S.S.R. a distance of $5,735 \mathrm{~km} .{ }^{5}$ Of the 1,008 Pectoral Sandpipers banded in 1960, two were recovered in the U.S.S.R.
TABLE 1.1 Summary of banding records attributed to C. S. Houston, permit 000460, in banding code order.

\begin{tabular}{|c|c|c|c|}
\hline SPECIES & BANDING YEARS & $\begin{array}{l}\text { \# OF } \\
\text { YRS }\end{array}$ & $\begin{array}{c}\# \\
\text { BANDED }\end{array}$ \\
\hline Western Grebe & $1944,59,77,81$ & 4 & 5 \\
\hline Red-necked Grebe & 1943 & 1 & 2 \\
\hline Horned Grebe & $1944,46,57,67,74$ & 5 & 6 \\
\hline Eared Grebe & 1957 & 1 & 58 \\
\hline Pied-billed Grebe & $1948,54,59$ & 3 & 3 \\
\hline Herring Gull & $1967,69,73,78$ & 4 & 45 \\
\hline California Gull & $1955-58,60-73,75-89$ & 32 & 9855 \\
\hline Ring-billed Gull & $1953-58,60-73,75-87,89$ & 35 & 20448 \\
\hline Franklin's Gull & $1957,60,65-68,70-72$ & 9 & 1330 \\
\hline Caspian Tern & $1956,64,65,69,73,78,85,89$ & 8 & 395 \\
\hline Common Tern & $1952,54,56-58,61,63-73,75-81,84,86$ & 26 & 3107 \\
\hline Black Tern & 1966,67 & 2 & 2 \\
\hline Double-crested Cormorant & $1953-58,60-61,63-73,75-87,89$ & 33 & 4674 \\
\hline American White Pelican & $1954-58,60,61,63-87$ & 31 & 5512 \\
\hline Common Merganser & $1974,76,83,92$ & 4 & 5 \\
\hline Red-breasted Merganser & 1969 & 1 & 1 \\
\hline American Black Duck & 1945 & 1 & 2 \\
\hline Ruddy Duck & 1948 & 1 & 1 \\
\hline Mallard & $1944-48,55-60,67,68,70,72,73,76,87-89,2001$ & 21 & 2029 \\
\hline Gadwall & $1943,52,60,67,75,77,83,86,90$ & 9 & 17 \\
\hline American Wigeon & $1943,44,45,46,48,52,59,60,67$ & 5 & 94 \\
\hline Green-winged Teal & $1943-46,48,57,58,76$ & 8 & 82 \\
\hline Blue-winged Teal & $1943-48,55,57,58,65-68$ & 13 & 1501 \\
\hline Northern Shoveler & $1943,45,46,48,57,58,60,64,65,67,68,71-73,88$ & 15 & 78 \\
\hline Northern Pintail & $1944-46,48,53,56-58,61,64,67,68,70,71,75$ & 17 & 642 \\
\hline Redhead & $1943-46,48,57,67$ & 7 & 378 \\
\hline Canvasback & $1943-46,48,67$ & 6 & 94 \\
\hline Lesser Scaup & $1943-46,48,58,64,71,77,79,83$ & 11 & 17 \\
\hline Ring-necked Duck & 1957 & 1 & 5 \\
\hline Common Goldeneye & $1958,74-89$ & 18 & 148 \\
\hline Bufflehead & 1945,75 & 2 & 11 \\
\hline White-winged Scoter & $1955-58,60,61,64,66-71,73,75,76,81,82,83$ & 19 & 113 \\
\hline Lesser Snow Goose & 1985 & 1 & 26 \\
\hline Ross's Goose & 1985 & 1 & 4 \\
\hline Greater White-fronted Goose & 1985 & 1 & 2 \\
\hline Canada Goose & $1946,67,78,81,85,87,88,92,95,2000,01,06$ & 12 & 51 \\
\hline Cackling Goose & 1985 & 1 & 2 \\
\hline Tundra[Whistling] Swan & 1974 & 1 & 5 \\
\hline American Bittern & $1943,44,46,48,55-57,69$ & 8 & 20 \\
\hline Great Blue Heron & $1944,53,54,57,58,69-71$ & 8 & 84 \\
\hline Black-crowned Night-Heron & $1944,46,47,48,55-57,64,68-71$ & 14 & 247 \\
\hline Sandhill Crane & 1987 & 1 & 1 \\
\hline Sora & $1944,53,61,68$ & 4 & 5 \\
\hline American Coot & $1943-46,48,58,60,67,69,71,77$ & 13 & 746 \\
\hline Red-necked Phalarope & 1967,70 & 2 & 4 \\
\hline Wilson's Phalarope & 1973 & 1 & 4 \\
\hline American Avocet & $1972,73,75,99,2003,05-07$ & 8 & 27 \\
\hline Wilson's Snipe & $1945,48,61,72,82$ & 5 & 12 \\
\hline Short-billed Dowticher & 1967 & 1 & 1 \\
\hline Long-billed Dowticher & 1967 & 1 & 1 \\
\hline Stilt Sandpiper & 1946,67 & 2 & 5 \\
\hline Pectoral Sandpiper & $1961,65,67$ & 3 & 19 \\
\hline Least Sandpiper & $1948,65,67,70$ & 3 & 110 \\
\hline Semipalmated Sandpiper & $1945,65,67,70$ & 4 & 162 \\
\hline Marbled Godwit & $1945,53,65,80,2007$ & 5 & 11 \\
\hline Lesser Yellowlegs & $1948,65,67$ & 3 & 15 \\
\hline Willet & $1944-46,56,63,73,74,79,87,96-98,2005$ & 13 & 23 \\
\hline Upland Sandpiper & $1944,61,68,84,86,91,99,2000$ & 8 & 12 \\
\hline Spotted Sandpiper & $1956,58,61,63-70,72,73$ & 13 & 37 \\
\hline Long-billed Curlew & $1961,74,78,81,87,88,95,2003$ & 8 & 15 \\
\hline Killdeer & $1946,48,52,53,57-59,61,64,65,67,70-75,79,81,83,85-92,97,99,2000-05$ & 36 & 121 \\
\hline Semipalamated Plover & $1965,67,70$ & 3 & 20 \\
\hline Piping Plover & $1963-73,84$ & 12 & 39 \\
\hline Ruffed Grouse & $1948,55,58,66,67$ & 4 & 4 \\
\hline Sharp-tailed Grouse & $1944,46,53,54,68$ & 5 & 5 \\
\hline Eurasian Collared Dove & $2003,05,06$ & 3 & 6 \\
\hline Mourning Dove & $1953,59,60,62-65,68,69,71,73,78,89,93,98,2002,05,08,09$ & 19 & 53 \\
\hline Turkey Vulture & $1972,74,2003-16$ & 16 & 1448 \\
\hline Northern Harrier & $\begin{array}{r}1944,46,52,54-57,59-61,64,66,67,69-78,80-83,87,80-83,87- \\
91,95,97,98,2000,01,05,06,08\end{array}$ & 40 & 526 \\
\hline
\end{tabular}




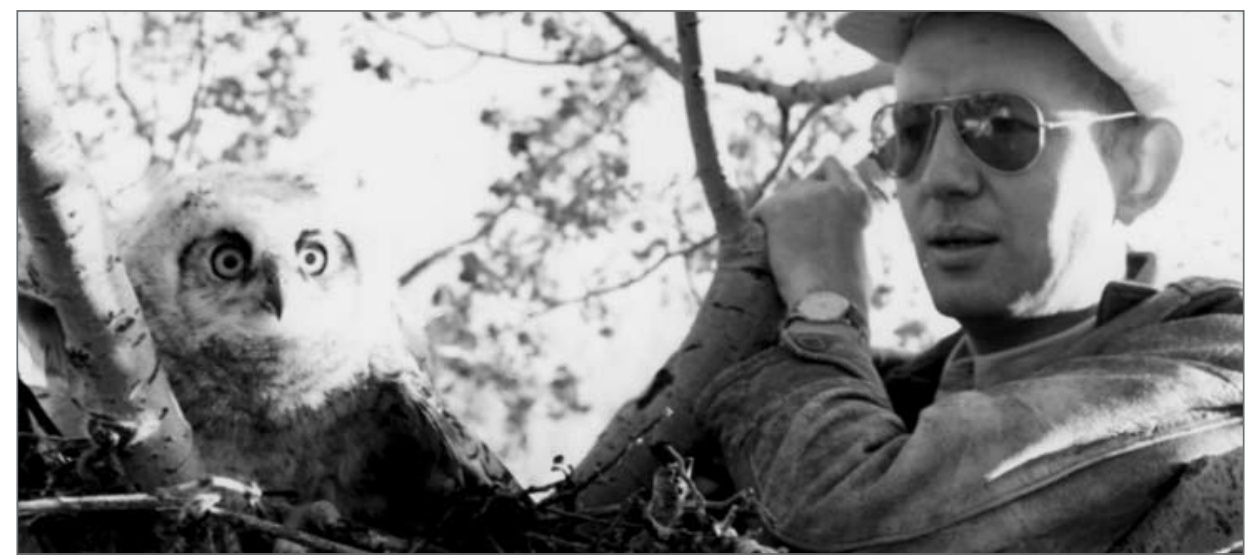

Stuart and a Great Horned Owl. Photo credit: Hans Dommach

Great Horned Owls became a special interest of Stuart's in 1958. Bill Horseman was able to climb a tree like a bear - he essentially walked up the side of the aspen on the soles of his running shoes while using his hands above to hold onto the tree trunk itself. While he was moving from slough to slough near Saltcoats, trapping muskrats, 15-year-old Bill had found 10 Great Horned Owl nests in which 22 young were banded. John Bull's summary of the seasons in Audubon Field Notes termed this "an outstanding piece of field work." 6 The banded Great Horned Owl nestlings total increased to 70 in 1959 and jumped to 151 in 1960 when three pairs of farm youngsters at Dubuc, MacNutt and Invermay each found 15 owl nests and earned a Peterson Field Guide apiece. Stuart's love relationship with Great Horned Owls brought his total to 7,776, (Table 1) before he turned his major species over to one of his many climber helpers, Dr. Martin Gerard, in 1994. "The success of an owl bander depends not so much on his own efforts as the help he receives from others... Most of the owl nests reported .... were in response to a request in Doug Gilroy's nature column, 'Prairie Wildlife,' in the Western Producer farm newspaper ..."7

In 1958, Maurice Street and his daughters visited Yorkton. A shallow pond beside Upper Rousay Lake held 10 Blue-winged Teal ducklings. Maurice sent the slowest runner, Mary Houston, deep into the muck of the shallow pond to scare the brood on to the dry grass of the shore. As the ducklings headed for the grass, Stan Houston, Margaret Belcher, Maurice and his two daughters caught all 10, including a final desperate rush of $100 \mathrm{~m}$ by Maurice. Four distant band recoveries (40 per cent!) resulted: McGregor, Minnesota (October 4, 1958); La Gorgona, Valle, Colombia (November 23, 1958); Tastus, Venezuela and Lake Ariguanabo, Bauta, Cuba (both in 1962). ${ }^{8}$

To band large numbers of birds per hour, and provide large numbers of recoveries, Stuart and Mary banded colonial birds on islands in lakes, with Redberry Lake their favourite site for American White Pelicans, Doublecrested Cormorants, California and Ring-billed Gulls, and Common Terns. The banded gull timing was perfect for R.F. Oldaker, who from 1958 to 1964 possessed infinite patience at the Vancouver city dump. He kept each banded California Gull (CAGU) in sight until all eight numbers around the circumference of a band could be recorded through his homemade telescope. Oldaker collected notebooks full of incomplete numbers, but managed to read 39 complete CAGU bands from Saskatchewan. California Gulls arrived in Vancouver on August 12, 1960, August 11, 1961 and August 11, 1963. They wintered along the Pacific coast, returned to the city dump when one and two and often three years old, and did not return to Saskatchewan lakes to breed until four years old!9

Ring-billed Gulls (RBGU) - 23,866 banded by four banders (Houston, Bard, McClanahan and Lyon) in Saskatchewan, with 538 recoveries - were so numerous they allowed separate mapping each month. The distance traveled southward was calculated between 10 and $35 \mathrm{~km}$ per average day for seven select RBGU. Of the total recoveries, $42.4 \%$ (228 birds) were in western Canada, 32.1\% (173 birds) were in 29 USA states and $25.5 \%$ were in 15 Mexican states with five states outside expected wintering range. Per cent recoveries of RBGU averaged $2.38 \%$, but showed a steady

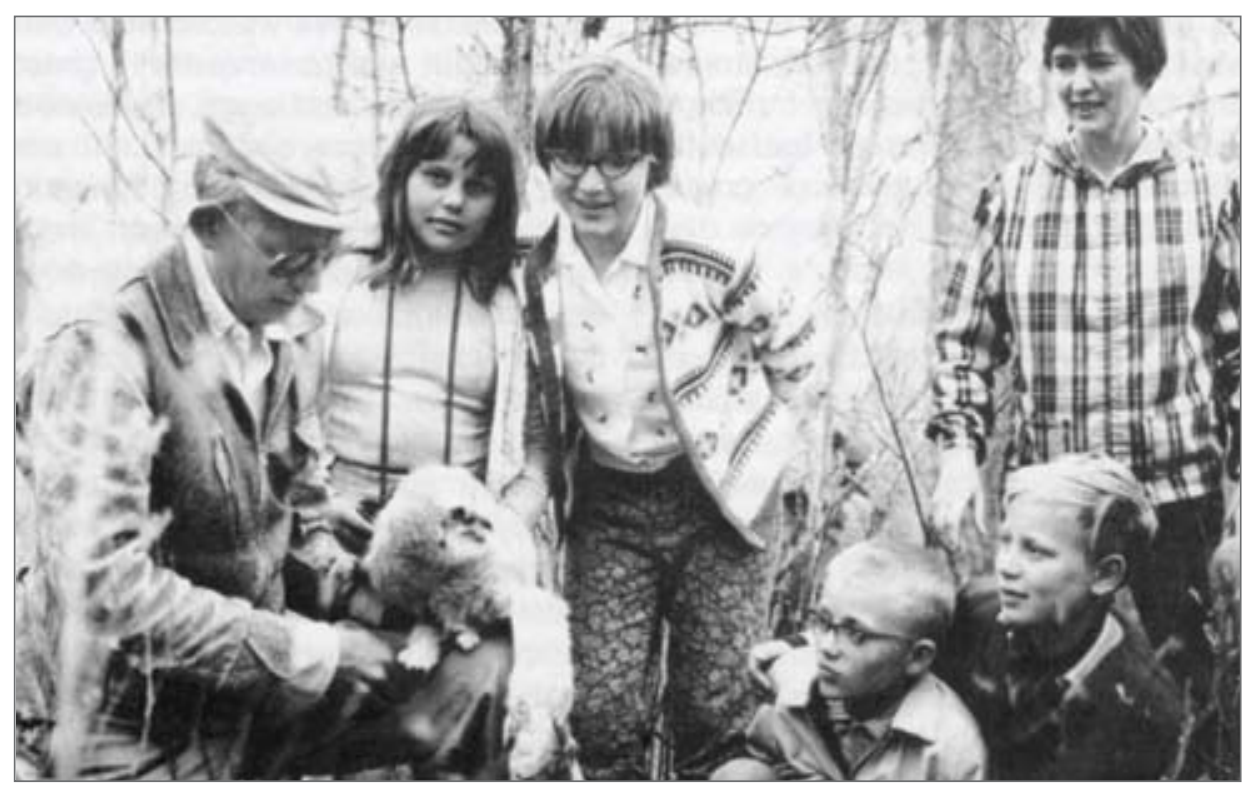

A group of Yellow Creek students observing a Great Horned Owl being banded by Stuart; Mary watching Photo credit: Rosemary Nemeth 
decline from as high as $5 \%$ before 1950 to less than $1 \%$ in 1979 and 1984. ${ }^{10}$

Franklin's Gulls $(1,330)$ banded at Rice Lake west of Saskatoon provided only two recoveries, one of which was noteworthy - a dead Franklin's Gull at Puerto Caldera, Chile on

February 3, 1973. ${ }^{11}$

Stuart and Mary jointly or individually have provided articles to The Blue Jay almost every year. Most recent articles include the vulture banding crew's wing-tagging efforts, and an article on the oldest Saskatchewan Osprey at 19 years, three months and Great Horned Owl at 25 years, nine months - two of our oldest and most-studied raptors. ${ }^{12}$

Mary, as a Stuart sub-permittee, has banded 8,021 Mountain Bluebirds and 20,815 Tree Swallows (Table 1) as part of a project for the [Nature] Saskatoon Junior Naturalists that began in 1969. Two hundred boxes, readily accepted by Mountain Bluebirds, were built in the Houston basement to "bring back the bluebirds" - from 10 young banded in 1969 to 21, 53, 157 and 329 in successive years, then dropping following adverse spring weather to 125 in 1983 and building back up to 403 in 1991. When Mary's arthritis prevented her from climbing highway ditches to birdhouses, she turned over the bluebird trail to Melanie Elliott and Greg Fenty in 2005. Gerald Parent had offered the perfect solution in 2001 for an elderly arthritic bander, seating Mary at a table beneath a beach umbrella and bringing her each Purple Martin in sequence $-4,886$ of them for her to band with ease over 16 years. Even more impressive, Mary holds the North American record for banding the most Bohemian Waxwings - 5,387. ${ }^{11}$ Her preferred method of capture for Bohemian Waxwings was baiting banding traps with Mountain Ash berries in their backyard. From dawn to dark on March 12, 1967, Mary handled 271 waxwings in a single day, banding 81 'new' bohemians and 190 'repeats.'13

Many people have helped Stuart
TABLE 1.2 Summary of banding records attributed to C. S. Houston, permit 000460, in banding code order.

\begin{tabular}{|c|c|c|c|}
\hline SPECIES & BANDING YEARS & $\begin{array}{l}\text { \# OF } \\
\text { YRS }\end{array}$ & $\begin{array}{c}\# \\
\text { BANDED }\end{array}$ \\
\hline Sharp-shinned Hawk & $1955,65,66,74,2005,08,09$ & 7 & 20 \\
\hline Cooper's Hawk & $1945,47,53,56,58,60,65,67,69,70,73-75,79,80,82,83,88-93,98-2009$ & 35 & 255 \\
\hline Northern Goshawk & $1955,65-67,72,78-81,92,97,98,2001,03,05,07-09$ & 17 & 45 \\
\hline Red-tailed Hawk & $1945,46,53,57-61,64-2009,11,12,16$ & 58 & 1095 \\
\hline Harlan's Hawk & 2004,09 & 2 & 2 \\
\hline Swainson's Hawk & $1944-46,48,53,55-58,60,64-2009,11-13,17$ & 58 & 4864 \\
\hline Broad-winged Hawk & $1965,74,78,84,97,98,2003,04,08$ & 8 & 15 \\
\hline Rough-legged Hawk & $1975,2000,01,04,05,08,09,12$ & 7 & 24 \\
\hline Ferruginous Hawk & $1958,60,61,69-2013$ & 47 & 4239 \\
\hline Golden Eagle & $1960,61,63-2002,08,09$ & 51 & 332 \\
\hline Bald Eagle & $1965,67,72,73,76,80,81,84-90,92,2000,01,09$ & 18 & 79 \\
\hline Gyrfalcon & $2002,07,10,11$ & 4 & 4 \\
\hline Prairie Falcon & $1959,70,71,73-2009$ & 40 & 813 \\
\hline Peregrine Falcon & $1960,61,81,2016,17$ & 5 & 14 \\
\hline Merlin & $1957,60,61,64,72-2012,14$ & 46 & 1069 \\
\hline American Kestrel & $1958-60,64-70,72-83,85-2009,17$ & 49 & 1087 \\
\hline Osprey & $1965,67,73,75-2004$ & 33 & 624 \\
\hline Long-eared Owl & $1947,52,58-61,64-69,71-81,83-94,96,97,99-2010,12,14,17$ & 52 & 749 \\
\hline Short-eared Owl & $1959,60,64,67,69,70,74,75,78,83,86,93,97,2001,02,05,06,08$ & 17 & 277 \\
\hline Barred Owl & $1960,61,88-93,2001,04,07$ & 11 & 19 \\
\hline Great Gray Owl & $1956,83,84,86,88,89,91,92,94,95,97,98,2000-07,09,10,12-14,17$ & 25 & 202 \\
\hline Boreal Owl & $1960,97,99,2001,05,08,09$ & 7 & 54 \\
\hline Northern Saw-whet Owl & $1959,60,64,67,72,73,2001,04-09,12,15$ & 14 & 1439 \\
\hline Eastern Screech-Owl & $1946,88,89$ & 3 & 18 \\
\hline Great Horned Owl & $1946,48,52-61,64-2009,11,14,17$ & 59 & 7776 \\
\hline Snowy Owl & $1954,67,2000-06,09,11,12,15$ & 13 & 107 \\
\hline Northern Hawk Owl & $1969,2000-14,16,17$ & 17 & 234 \\
\hline Burrowing Owl & $1947,61,67,88$ & 4 & 14 \\
\hline Black-billed Cuckoo & 1963 & 1 & 1 \\
\hline Belted Kingfisher & 1959 & 1 & 13 \\
\hline Hairy Woodpecker & $1956,61,82,84,85,87-89,92,95,97,2004,09,13,16$ & 15 & 24 \\
\hline Downy Woodpecker & $1954,55,57,60,61,85,88,92,2000,04,08,09,10,16$ & 13 & 22 \\
\hline $\begin{array}{r}\text { Yellow-bellied } \\
\text { Woodpecker(Sapsucker) }\end{array}$ & $1954,59-61,65,67,69,70,91,2008$ & 10 & 16 \\
\hline Pileated Woodpecker & $1970 \& 2008$ & 2 & 8 \\
\hline Yellow-shafted Woodpecker & $1945-47,49,53,56,59,65-69,71,72,78,85,95,96,98-2006,08-10,12-14,16$ & 33 & 118 \\
\hline Red-shafted Woodpecker & 2007 & 1 & 1 \\
\hline Common Nighthawk & $1945,46,63$ & 3 & 4 \\
\hline Ruby-throated Hummingbird & 1946,48 & 2 & 3 \\
\hline Eastern Kingbird & $1944,65,67,69,70,72,73,75,79$ & 9 & 40 \\
\hline Western Kingbird & $1971,73,75,80,83,2000,02,04$ & 8 & 44 \\
\hline Eastern Phoebe & $1958,65,66,87,2001,06$ & 6 & 40 \\
\hline Say's Phoebe & 1968 & 1 & 5 \\
\hline Yellow-bellied Flycatcher & 1965,68 & 2 & 3 \\
\hline Western[Alder] Flycatcher & $1965,66,68$ & 3 & 10 \\
\hline Least Flycatcher & $1945,55-58,61,65,66,69$ & 9 & 36 \\
\hline Horned Lark & $1967,74,82,2003,05$ & 5 & 5 \\
\hline Black-billed Magpie & $1954,58-61,64-2009,10-13,15,16$ & 55 & 1302 \\
\hline Blue Jay & $1959,71,76-82,84-2016$ & 42 & 294 \\
\hline Gray Jay & $1952,2006,08,09$ & 3 & 14 \\
\hline Common Raven & $1968,90,95,2000,02-09$ & 12 & 109 \\
\hline American Crow & $1945,52-54,57-61,64-69,71-75,77-93,95,97-2007$ & 49 & 592 \\
\hline European Starling & $1955,57,59,64-67,69,71,87,88,2000,02,05,06$ & 15 & 77 \\
\hline Brown-headed Cowbird & $1961,65,66,69,99,2000,06,12,15$ & 9 & 15 \\
\hline Yellow-headed Blackbird & $1961,66-68,70-72$ & 8 & 49 \\
\hline Red-winged Blackbird & $1944,45,58,62,65,67,68,73,74,78,2000,02,03,05$ & 14 & 74 \\
\hline Western Meadowlark & $1945,54,2005$ & 3 & 9 \\
\hline Baltimore Oriole & $1946,47,53,59-61,64-66,68,70,71$ & 12 & 21 \\
\hline Brewer's Blackbird & $1967,68,72,78,91-93,99,2003-06,14$ & 13 & 35 \\
\hline Common Grackle & $1944-54,56,60-71,73-82,84-2016$ & 70 & 1346 \\
\hline Evening Grosbeak & $1959,68,70-73,75,76,78,83-89$ & 15 & 943 \\
\hline Pine Grosbeak & $1969,72,86$ & 3 & 44 \\
\hline Purple Finch & $1953-55,57,60,65,67,68,71-73,76-79,81,83,84,86,89,96,98-2000,02,03,11,12,15,16$ & 33 & 416 \\
\hline House Finch & $\begin{array}{ll}1995-2017\end{array}$ & 22 & 955 \\
\hline Red Crossbill & $1964,70,73,96$ & 4 & 34 \\
\hline White-winged Crossbill & 1969,88 & 2 & 5 \\
\hline Hoary Redpoll & $1960,66,69,72,74,78,86,88,92,2000,02,04,07,13$ & 14 & 39 \\
\hline Common Redpoll & $\begin{array}{r}1960,62,64,66,69,70,72,74,76,78,85,86,88-90,92,94-96 \\
2000,02,04,05,07-09,13\end{array}$ & 27 & 3226 \\
\hline American Goldfinch & $1958,67,90,2013-15$ & 6 & 12 \\
\hline
\end{tabular}


find nesting raptors, climbed trees to the nests, gone over cliffs attached by rope and climbing harnesses or herded smelly young pelicans and cormorants at Redberry Lake in the early morning hours before the sun got so hot that it could give heatstroke to nestlings no longer sheltered by their parents. What follows are heavily edited excerpts of such remembrances:

\section{Leif Nordal, Bulyea, farmer, naturalist and excellent nest finder. His son Gary said "Dad passed away three years ago but liked to spend his springs driving the countryside looking for owl nests."}

Sig Jordheim, Kyle, naturalist, farmer at $\mathbf{9 5}$ years young recalls. "A Swainson's Hawk struck Stuart's head and flew off with his cap. A Golden Eaglet in Prime Coulee took flight; I retrieved the bird and placed it back in its nest to be banded. Stuart was always in a hurry to get to the next banding site."

Frank Roy, Tullis/Saskatoon, childhood pen pal, long time friend, teacher, naturalist, and Stuart's publication editor. "I recall going to Redberry Lake to band pelicans and cormorants which puked on me as I sat in the back of the boat. I told Stuart I was not coming banding again!"

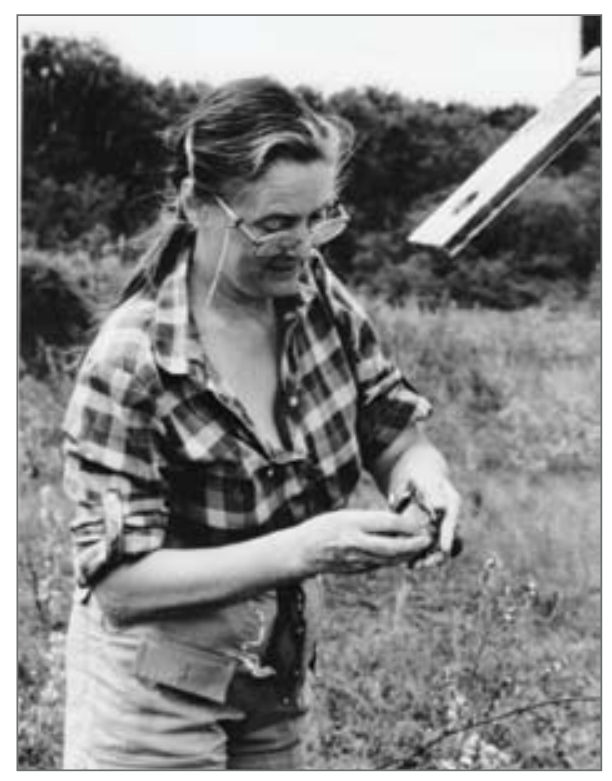

Mary banding a bird. Photo credit: Lynn Oliphant

\section{Doug Whitfield, Saskatoon,} naturalist, banding crewmember. "In 1965, I reported a Great Horned Owl nest and was invited to witness the banding of its young. I soon became a regular participant in Stuart's banding activities, where I met and befriended Jon Gerrard. This led to several years of widespread eagle banding in northern Saskatchewan and a contract from the CWS to carry out a quantitative survey of the Saskatchewan eagle population ... Without Stuart's enthusiastic mentorship none of this would have happened. Our knowledge of the province's Bald Eagles would still be stuck at 1966 levels. It is hard to overestimate the effects on my life from knowing him."

\section{Lorne Scott, Indian Head,} naturalist, master bander, former NDP Minister of Environment, retired Reeve of his RM. "In one of Doug Gilroy's Prairie Wildlife Columns in the Western Producer in the winter of 1966, there was a note, please contact Stuart if you know of Great Horned Owl nests. I wrote that I knew of three nests at Indian Head. Stuart replied that he would come. My Dad was sceptical that anyone would travel 200 miles to band owls. Sure enough, a well-used vehicle with aluminum ladders on the roof roared

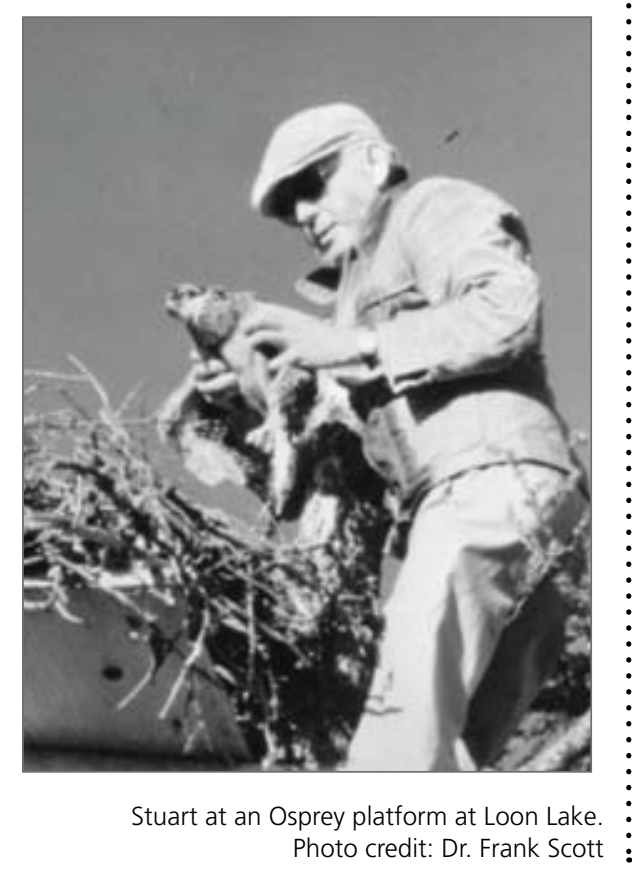

into the farmyard, scattering chickens and sending the dog under the porch. Stuart and his crew, including Doug Whitfield, never left the vehicle, saying 'Jump in, we need to band the owls and be on our way.' Dad was shaking his head; no one had ever come to his farm without coming into the house for a visit. Stuart returned in June to band nestling Red-tailed Hawks.

A life-long friendship has been maintained, with Stuart and Mary as mentors, advisors, critics and a steadfast source of inspiration and encouragement. Countless others have also been introduced to nature conservation and some have pursued life-long careers in the wildlife field. For 70 years, thousands throughout Saskatchewan have benefited from their passion, knowledge, dedication and encouragement. What a legacy!"

Wayne Renaud, Valley Centre/ Toronto, naturalist and wildlife consultant. "My brother Don and I first met Stuart on July 7, 1968 when he came to band a brood of Longeared Owls near Valley Centre. On June 8,1969 , his entourage banded young in nests of six Short-eared and six Long-eared Owls and nests of Northern Harrier, American Crow, Black-billed Magpie and European Starling. Stuart was instrumental in my decision to go to university

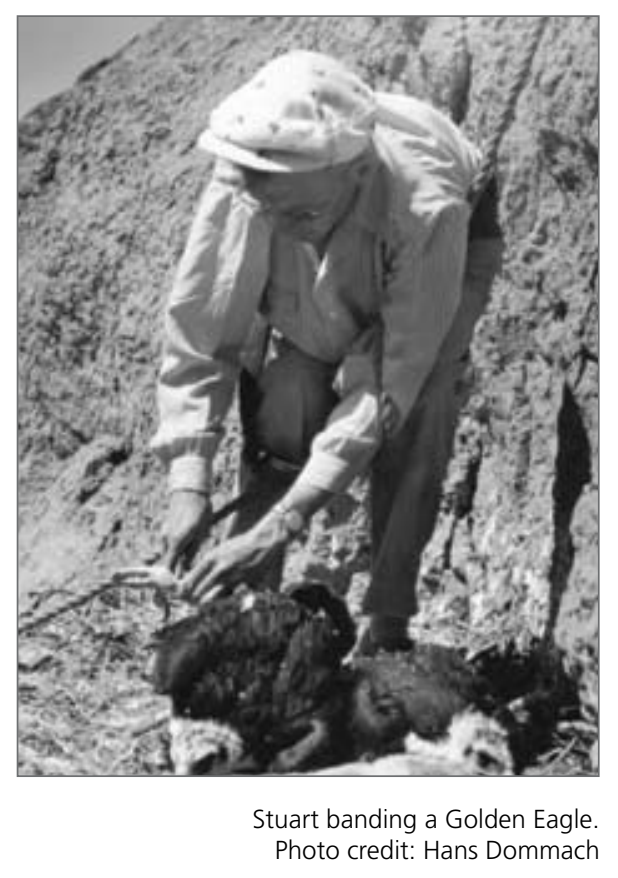


instead of a technical school. During five years working on my B.Sc. in Saskatoon I helped band Golden Eagles, Prairie Falcons, Ferruginous and Swainson's Hawks, Great Blue Herons, American White Pelicans, Double-crested Cormorants, Ring-billed, California, Franklin's and Herring Gulls. Always the consummate team player, he and Mary ... hosted dinners at their house."

\section{Spencer Sealy, Battleford/ Winnipeg, PhD ornithologist, professor emeritus University} of Manitoba. "My banding began when I was a high school student in Battleford, focused then on birds of prey. When I had a tally of upcoming nestlings soon ready for banding, I notified Stuart by letter and he sent me the appropriate number of bands in the mail, or on the bus. At the first Great Horned Owl nest, I was struck in the face by the female owl; wearing safety glasses and a leather jacket, the damage was minimal, but I became ever more careful ... In 1962, I obtained my own banding permit, with a strong and convincing supportive letter from Stuart to the banding office." Spencer was assisted by climbers: brother Ted Sealy, and Harold Fisher, now a well-known bander near Prince Albert (pers.com. CSH).

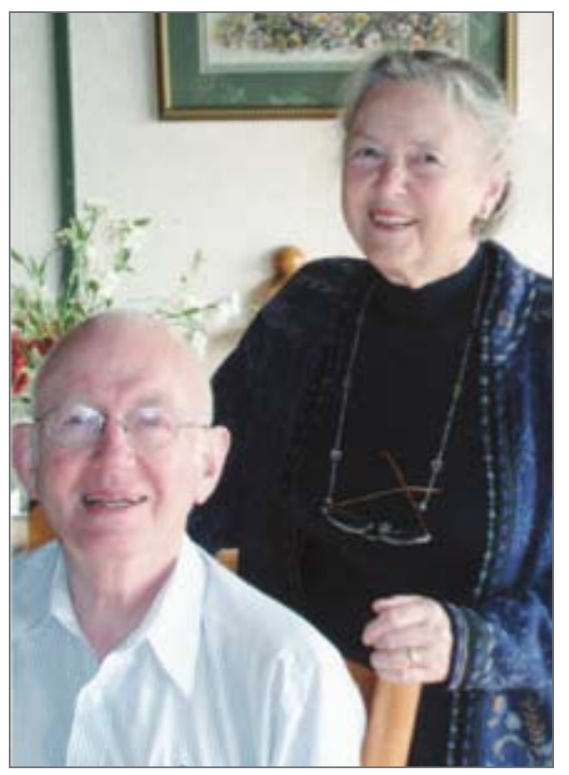

Stuart and Mary Houston - September 28, 2006 Photo credit: Bob Lampard

TABLE 1.3 Summary of banding records attributed to C. S. Houston, permit 000460, in banding code order.

\begin{tabular}{|c|c|c|c|}
\hline SPECIES & BANDING YEARS & $\begin{array}{l}\text { \# OF } \\
\text { YRS }\end{array}$ & $\begin{array}{c}\# \\
\text { BANDED }\end{array}$ \\
\hline Pine Siskin & $1964-69,72,73,84,91,92,94-2002,04-17$ & 33 & 1429 \\
\hline Lapland Longspur & 1960 & 1 & 1 \\
\hline Vesper Sparrow & 1965,2006 & 2 & 16 \\
\hline Baird's Sparrow & 1945,64 & 2 & 3 \\
\hline Savannah Sparrow & $1945,62,65,67,70,2014$ & 6 & 59 \\
\hline Grasshopper Sparrow & 1964 & 1 & 1 \\
\hline Harris's Sparrow & $1944,45,54-61,63-68,74,75,81,94-2017$ & 43 & 401 \\
\hline $\begin{array}{r}\text { Eastern White-crowned } \\
\text { Sparrow }\end{array}$ & $1996,2000,05,07,08,13-17$ & 7 & 18 \\
\hline $\begin{array}{r}\text { Gambel's White-crowned } \\
\text { Sparrow }\end{array}$ & $1945,46,52,55-69,72,74,94-2017$ & 48 & 789 \\
\hline White-throated Sparrow & $1944,45,49,52-56,58-69,71,72,74,75,77,80-82,88-20117$ & 57 & 4475 \\
\hline American Tree Sparrow & $1955-61,63-65,67-69,98,2004-12,14,16,17$ & 26 & 115 \\
\hline Chipping Sparrow & $1945-48,52,53,59,60,63-66,68,69,92,95-97,99-2005,07-2017$ & 36 & 390 \\
\hline Clay-colored Sparrow & $1945,55-60,63-70,96,97,2004,05,07-11,14,16,17$ & 26 & 375 \\
\hline Slate-colored Junco & $1945,54-61,63-70,73-85,87-2017$ & 61 & 7846 \\
\hline Oregon Junco & 1967 & 1 & 2 \\
\hline Song Sparrow & $1958-61,63-67,69,2005,08,09,15,16$ & 15 & 55 \\
\hline Lincoln's Sparrow & $1945,46,53,58-69,72,79,81,88,92,96-2017$ & 43 & 717 \\
\hline Swamp Sparrow & $1967,69,2010$ & 3 & 4 \\
\hline Fox Sparrow & $1958,61,65-69,74,89,2005,07-15$ & 19 & 88 \\
\hline Spotted Towhee & $1964-66,75,95,2011,12$ & 7 & 16 \\
\hline Northern Cardinal & 1980 & 1 & 1 \\
\hline Rose-breasted Grosbeak & $1956,58,61,64-66,68,70,95,96,2002,05,13-15$ & 15 & 30 \\
\hline Indigo Bunting & 1961 & 1 & 1 \\
\hline Lark Bunting & 1960 & 1 & 1 \\
\hline Western Tanager & 1979 & 1 & 1 \\
\hline Purple Martin & $1954,57,59,81,2001-16$ & 20 & 4886 \\
\hline Cliff Swallow & 1958 & 1 & 1 \\
\hline Barn Swallow & $1945,53,56,58,60,63,65,67-78,80-82,84,85,89,90,2003,04,06$ & 29 & 628 \\
\hline Tree Swallow & $1946,69-2009,11$ & 43 & 20914 \\
\hline Bank Swallow & $1944,45,54,67,71,81$ & 6 & 130 \\
\hline Bohemian Waxwing & $1953,58,60-72,74-79,85,87-89,91,94,95,97,99,2000,01,03,05-08,11,13,14,16$ & 41 & 5392 \\
\hline Cedar Waxwing & $1956,58-61,66-68,72,73,78,79,87,91,99,2002,05,07,08,10,15$ & 21 & 86 \\
\hline Northern Shrike & $1977,85,88,2004,06,08,09,12$ & 8 & 17 \\
\hline Loggerhead Shrike & $1955,64,68,69,71-75,79,81,84,88,94-2008,10$ & 29 & 415 \\
\hline Red-eyed Vireo & $1960,61,65,67,79$ & 5 & 14 \\
\hline Philadelphia Vireo & $1965,67,69$ & 3 & 4 \\
\hline Warbling Vireo & $1965,67,69$ & 3 & 3 \\
\hline Blue-headed Vireo & $1958,65,67$ & 3 & 4 \\
\hline Black-and-white Warbler & $1959,65,66,69,79,2016$ & 5 & 12 \\
\hline Nashville Warbler & $1955,57,61,67,2016$ & 5 & 6 \\
\hline Orange-crowned Warbler & $1957-61,65-69,2006,10,13-15$ & 15 & 154 \\
\hline Tennessee Warbler & $1955-60,62-69,79,2014$ & 16 & 125 \\
\hline Cape May Warbler & $1960,65,66,68$ & 4 & 11 \\
\hline Yellow Warbler & $1946,5456,58,60,63,65,66,68,69,71,2001,10-12,14-16$ & 18 & 63 \\
\hline $\begin{array}{r}\text { Myrtle[Yellow-rumped] } \\
\text { Warbler }\end{array}$ & $1944,49,54-61,63-69,71,74,77,2002,03,07,09-12,15,16$ & 29 & 339 \\
\hline Magnolia Warbler & $1959-61,65,67-69,79,2007$ & 9 & 18 \\
\hline Chestnut-sided Warbler & 1965,66 & 2 & 3 \\
\hline Bay-breasted Warbler & $1960,65,67-69$ & 5 & 17 \\
\hline Blackpoll Warbler & $1955,58,63,65-69,2009,10$ & 10 & 67 \\
\hline Western Palm Warbler & $1956,58,59,64,66,67,2002$ & 7 & 8 \\
\hline Ovenbird & $1945,58,61,64-70,79,92,2003,06,08-10,13-17$ & 22 & 156 \\
\hline Northern Waterthrush & $1945,49,57,59-61,64-69,84,2016$ & 14 & 64 \\
\hline Connecticut Warbler & $1967 \& 2013$ & 2 & 2 \\
\hline Mourning Warbler & $1954,61,65-68,79,2010$ & 8 & 19 \\
\hline Common Yellowthroat & $1958,60,65-69,2015$ & 8 & 21 \\
\hline Wilson's Warbler & $1960,61,65-70,79$ & 9 & 29 \\
\hline Canada Warbler & 1965,79 & 2 & 3 \\
\hline American Redstart & $1954,61,65-69,79$ & 8 & 31 \\
\hline House Sparrow & 2005-2009 & 5 & 10 \\
\hline American Pipit & 1967 & 1 & 2 \\
\hline Gray Catbird & $1945,53-56,58,60,64-66,69,2014-16$ & 15 & 37 \\
\hline Brown Thrasher & $1955-57,59,64-66,69,72,74,82,2003,11,14-16$ & 15 & 30 \\
\hline House Wren & $1945-47,54,57,59,60,66-69,74,76-85,87-2001,03-06,08,10-15$ & 47 & 474 \\
\hline Brown Creeper & $1953,56,57,59,69$ & 5 & 6 \\
\hline White-breasted Nuthatch & $1976-78,82,88,90,92,2004,07,10-13$ & 12 & 16 \\
\hline Red-breasted Nuthatch & $1959,60,65,68-70,72,74,75,77-81,83,85-91,93-2016$ & 45 & 186 \\
\hline Black-capped Chickadee & $1948,52-68,71-2017$ & 65 & 1455 \\
\hline
\end{tabular}


Glen Fox, Kindersley, naturalist, friend and banding sub-permittee.

"I was one of Stuart's sub-permittees and banded in the Kindersley area. He was a HUGE influence in my birding career. I learned to mist net with Stuart and Mary at Beaver Creek. The most memorable occasion was a week or so one autumn 60 years ago, where Sandy Macaulay (future Ducks Unlimited Biologist) and I mist-netted and banded shorebirds with and for Stuart and Mary, at Rice Lake, a wetland west of Saskatoon, my first experience with shorebirds in the hand."

\section{Harold Fisher, Battleford/Prince Albert, naturalist, retired high school teacher, master bander.} "Strangely enough, I have never been on a banding excursion with Stuart! ... Quite unusual for a man whose influence on me has been so profound ... In 1962 or 63, I became friends with Spencer Sealy, a protégé and sub-permittee of Stuart's. He was five years older but we made a great banding team, in part because I was a fearless and skilled tree climber. Spencer instilled in me a life-long passion for birds and the need for proper documentation of natural events ..." [Harold Fisher met Stuart in the late summer of 2007] "when my daughter Shelly was awarded the Houston prize in Ornithology from Gary Bortolotti, we joined Stuart and Mary for tea at their home."

"Within a week I had a banding sub-permit and mist nets set up for Saw-whet Owls. And so began the nightly ritual of checking nets, banding owls, and submitting a daily log of data to Stuart via email. Every detail had to be checked for accuracy ... he encouraged me to procure a master permit and has been my advisor in almost every aspect of my banding. During the last few years of Stuart's Turkey Vulture program, I became part of the wing-tagging team and actually accompanied Stuart afield to a new Turkey Vulture site. Stuart's accomplishments, 75 years of banding, hundreds of books and publications, the hundreds of thousands of birds banded - all simply incredible. Stuart has set the bar for those who follow."

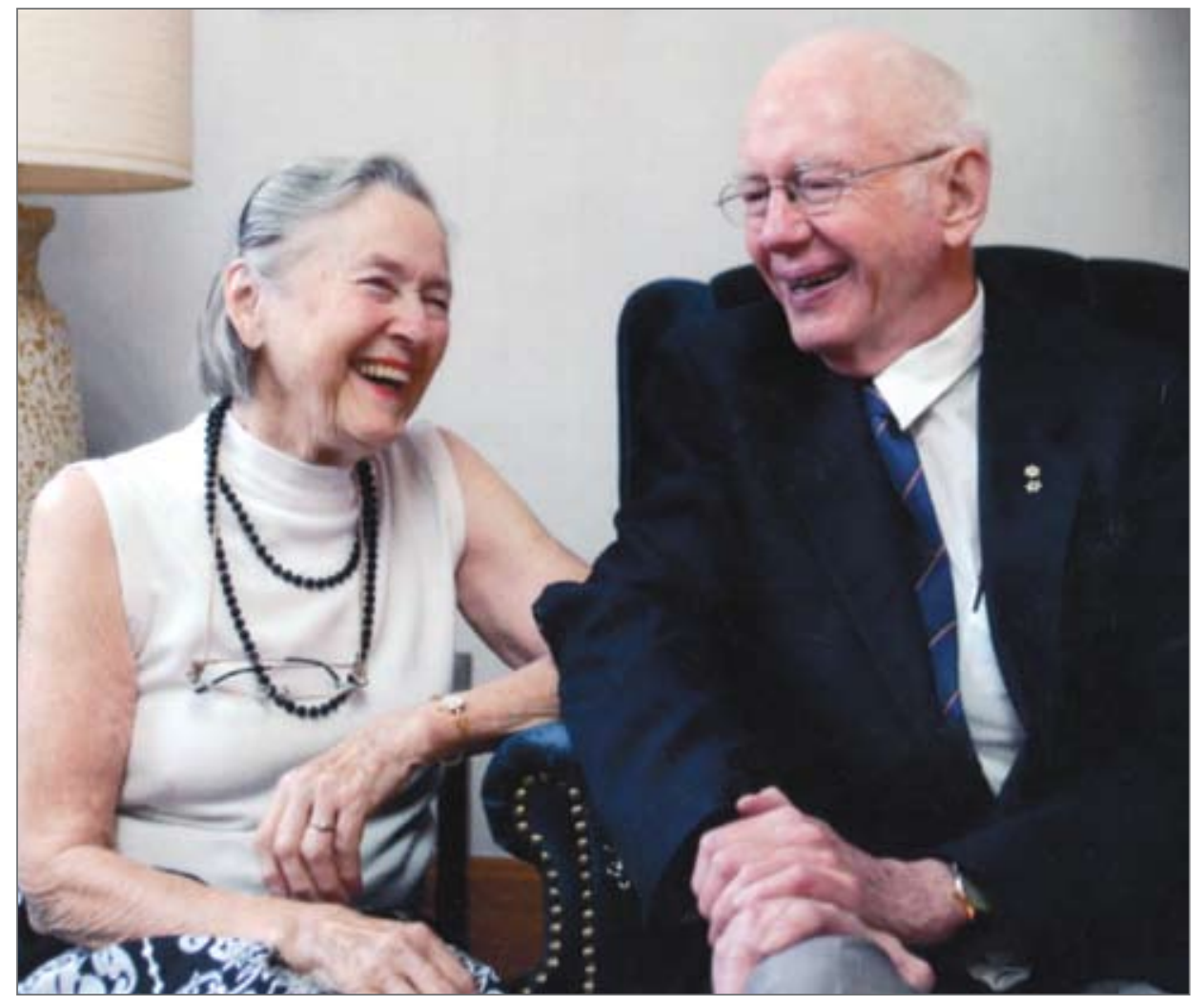

Mary and Stuart. Photo credit: David Stobbe
Penny Davis and Frank Scott, Loon Lake/Saskatoon, MDs, pilots, naturalists. "What sticks in our minds about Stuart's banding in Loon Lake area was the way he and Mary were able to encourage and engage young would-be banders and tree climbers. His favourite tree to climb in Loon Lake, we always kept for him to band on, lots of branches and a perfect angle! We called it 'Stuart's tree'. We roasted a lamb for the BBQ during the Osprey weekends. The first weekend we planned to eat early. Stuart was so eager to go out again after dinner to band more birds that he stood next to the barbecue and cut meat off the outside of the lamb as it cooked so that one more nest could be banded before nightfall! In consideration of us on Sunday morning, Stuart decreed early morning banders made their own coffee and breakfast. Finally, we have Stuart and Mary to thank for making wonderful banding (and slightly crazy) friends over many years."

\section{Jon Gerrard, Saskatoon/} Winnipeg/Ottawa, MD, a federal MP, and junior cabinet minister. "Growing up in Saskatoon in the 1950s and 60s, I was fortunate enough to be invited on banding expeditions with Stuart and Mary Houston. These ranged from banding migratory warblers and sparrows, to rappelling down a cliff to band Golden Eagles.

One of my favourites was getting up at 2 a.m., having breakfast with Stuart and Mary at their home and heading to Redberry Lake... Occasionally, it was also possible to catch a White-winged Scoter coming off its nest. When I was eight and nine, my job was to catch as many young gulls as possible and bring them to Stuart or Mary. We had come suitably prepared with old clothes and a hat for protection from white squirts of excrement.

I also revelled going with Stuart to band Great Horned Owls. Stuart repeatedly reminded us of two young men near Yorkton who had each lost an eye when climbing to a Great Horned 
Owl nest. A parent owl swooped in noiselessly and inserted its talon into the human eye ... As he drove, Stuart would regale us with stories.

I learned about keeping meticulous records. I learned bird identification by sight and by song, I learned about looking after our environment and I developed a great appreciation not only for wildlife but also for the history of Saskatchewan and particularly the history of the early bird watchers and record keepers ... On long weekends, we would travel with a cooler filled with sandwiches, oatmeal cookies, and gallon thermoses of iced tea, carefully prepared by Mary. In the evening, we would stay in a small town hotel - with its beds often only there because they were a requirement if the establishment wanted to have a bar. It was as Stuart said 'seeing Saskatchewan first.' I have followed in Stuart's footsteps becoming a physician and having an avocation banding birds - in my case Bald Eagles at or near Besnard Lake in northern Saskatchewan. Stuart Houston was an example in recording and in writing up our findings enabling our eagle project to continue every year since 1967. Thank you, Stuart and Mary, for inspiring me and so many others to become involved with birds."

\section{Ross Lein, Saskatoon/Calgary, $\mathrm{PhD}$, ornithologist, biology professor University of Calgary.}

"I went banding with Stuart, Mary and their oldest son Stan on only one occasion, to Redberry Lake to band gulls in the summer of either 1966 or 1967. First, Stuart maintained a stream of stories related to banding or ornithological history, during the trips up and back. Second, there was a single-minded attention to banding as many birds as we could during the shortest possible time. Although an 'amateur' in a field that was becoming, and has become, increasingly professionalized, Stuart's drive and enthusiasm in banding many thousands of birds resulted in important insights into the biology of a number of species.

\section{TABLE 1.4 Summary of banding records attributed to}

C. S. Houston, permit 000460, in banding code order.

\begin{tabular}{|c|c|c|c|}
\hline SPECIES & BANDING YEARS & $\begin{array}{l}\text { \# OF } \\
\text { YRS }\end{array}$ & $\begin{array}{c}\# \\
\text { BANDED }\end{array}$ \\
\hline Boreal Chickadee & 1953,87 & 2 & 2 \\
\hline Golden-crowned Kinglet & $1967-69,99,2010$ & 5 & 14 \\
\hline Ruby-crowned Kinglet & $1956,60,65-69,2005$ & 8 & 17 \\
\hline Townsend's Solitaire & 1987 & 1 & 1 \\
\hline Veery & 1966 & 1 & 1 \\
\hline Swainson's Thrush & $1955,56,58-61,64-70,79.2003,04,06-16$ & 27 & 297 \\
\hline Grey-cheeked Thrush & $1955,56,58,61,65-69,71,96,2002,10$ & 13 & 116 \\
\hline Hermit Thrush & $1955,57-59,61,63,65-69,72,74,2003-06,08,15$ & 19 & 158 \\
\hline American Robin & $1944-61,63-70,72,74,76-78,85,87,91,92,94-97,99-2016$ & 57 & 493 \\
\hline Varied Thrush & $1984,2008,14$ & 3 & 3 \\
\hline Eastern Bluebird & $1966,74,75,77,78,86,95,97,98,2007$ & 10 & 54 \\
\hline Mountain Bluebird & $1966,69-2009$ & 42 & 8028 \\
\hline $\begin{array}{r}\text { Hybrid bluebird, Eastern/ } \\
\text { Mountain }\end{array}$ & 1974 & 1 & 5 \\
\hline & & Total & 151888 \\
\hline
\end{tabular}

In addition, his life-long interest in the history of ornithology and banding in Saskatchewan and western Canada has documented the development of our understanding of the bird life over several centuries. Thirdly, he has encouraged and mentored dozens of individuals with an interest in birds. Many of these have assisted in his banding projects (and continued their own) and a number have gone on to careers related to ornithology. I was one of a cohort of Saskatchewan teenagers in the late 1950s and 1960s whom, at least in part as a result of Stuart's example and encouragement, pursued occupations that 'let them spend their time doing what they loved. '"

Moe Mareschal, Birch Hills, naturalist, retired high school biology teacher, Canadian Army Reservist. "Stu made a commendable effort to keep those people in the loop who helped locate raptor nests with young. Some of my former students still remember watching the climbing and banding. My most memorable episode of 'Banding with Houston' occurred when during a five-year stint with the Reserve Army, I was late in returning from a training session. Stu and Crew were waiting at our home; I finally arrived and was hustled, still in Battle Dress, into Stu's venerable Toyota Land Cruiser. Off we went at a rather high speed ... booting east past the elevators in Birch Hills when there were flashing lights and a RCMP siren. Stu rolled his window down to tell the Corporal that we had two owl nests to visit quickly before total darkness. He leaned down and looked at me, ignoring Stu momentarily to shout, 'Mareschal, what the hell are you up to now?' Silence rang loudly for a few heartbeats, but I waved at the policeman. The RCMP decided that the paperwork wasn't worth the effort and let us go into the gathering darkness where we banded at only one nest; the other was in a dead aspen and not safe. Later I received a phone call from the local United Church asking why Dr. Stuart Houston was making a donation to the Church's renovation plan in my name. The donation was equal to the normal fine for speeding."

\section{David Miller, Saskatoon,} physiotherapist, banding crew member and Great Horned Owl crew leader. "Had Dr. Houston's talk to the Natural History Society in 1986 been less engrossing, had his slides of owls, eagles, hawks, and falcons been less enthralling, and had his invitation to join his banding expeditions (with the added inducement of 'all the peanut butter and raisin sandwiches you can eat') been less exciting, I might have paused to contemplate my pathological fear of heights before I strode forward to volunteer. But as they say, 'fools rush in..

Stuart is an inexhaustible font of information on any number of topics: 
ornithology of course, and the history of Canada and the fur trade and medicine, and ... the list goes on. He's a born teacher, and his enthusiasm is infectious. At the end of a weekend of banding, I have my head stuffed full of fascinating details about bird behaviour, the early days of medicare in Swift Current, where to look for the signs of tuberculosis on a chest X-ray, and why it is essential to know the legal land description of your father's farm. I see the world through new eyes.

There is a sense of ritual and festival to the banding expeditions. Stuart promises the banders that they will meet 'the nicest and most observant people in Saskatchewan - most observant because they find the owl nests, and nicest because they take the trouble to tell me about them.' And in this, as in so many things, he is right. The arrival of the banders is special, too, for the families who have been reporting nests to Stuart for years. 'There would be something missing

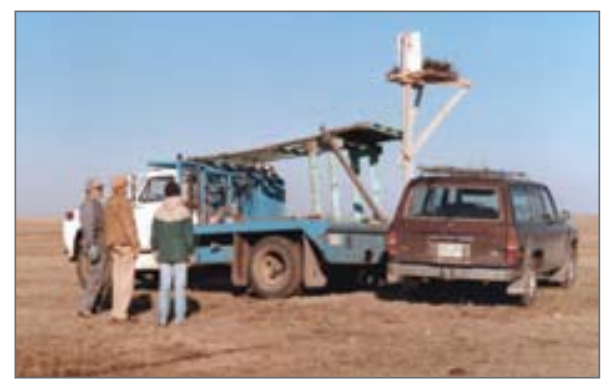

Osprey platform. Photo credit: Jean Harris

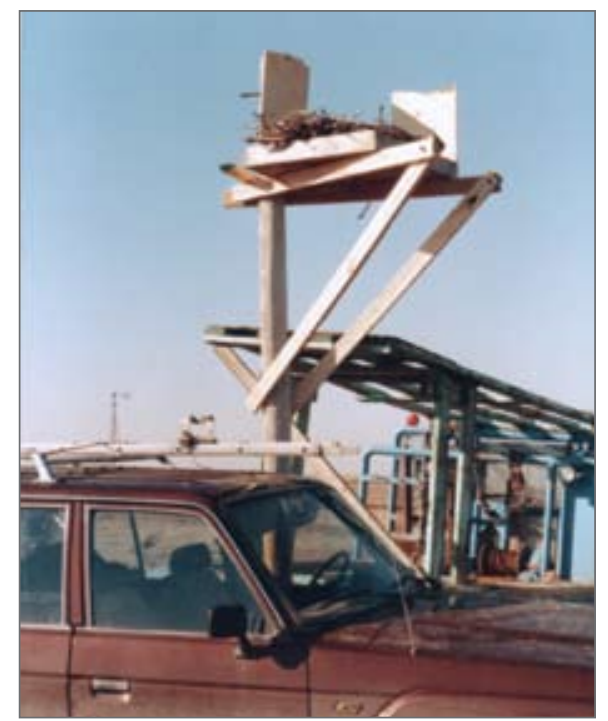

Ferruginous Hawk nesting platform. Photo credit: Jean Harris from the spring,' a farmer tells me, 'without Dr. Houston and his crew.'

But Stuart himself sums up the attraction of bird banding best: 'It's the greatest field sport known to man.'"

Kelly Wylie, Saskatoon/Ottawa, computer consultant, naturalist, banding crewmember. "My first recollection of Stuart was on a nature outing near Saskatoon. There was a need for someone to climb a tree to inspect a Goldeneye nest cavity. I volunteered. As I descended, Stuart said to me "I should take you banding with me." That was the start of a long friendship and many climbs to nests with young requiring bands on their leg. Full helmet and leather jacket were a necessity with Goshawks, as they would almost always try to knock the climber out of the tree. I remember: sitting in the nest with a Bald Eagle that was almost full size, trying to distract it while also trying to grab both of its feet before it could grab me; tying a rope just under the nest and throwing it over to another tree then climbing down and up the other tree and pulling the first tree over so I could reach into the initial nest; running back to the truck from a nest tree because we were in a hurry and then being VERY grateful that I was running because the skunk that I did not see missed when it tried to spray me; being amazed at Stuart's incredible memory for nest sites he could drive right to them in the middle of nowhere and rarely had to refer to his old leather briefcase full of Saskatchewan topographical maps; driving backward - sometimes there was nowhere to turn around so we had to back out. Mary joked about Stuart having spent almost as much time backing up as driving forward.

Mary Houston was part of the support team for those trips. Among other things, she ensured that we had plenty of food, iced tea and water. The coolers were always ready to go. She must have spent many hours making sandwiches. I developed quite a liking for the peanut butter and raisin sandwiches. In addition, she had her own (backyard) banding projects.

I also assisted Stuart with his computer banding entries, making him one of the first Canadian banders to submit all his banding records by computer - and he had a LOT of records to submit each year. This was in the 1980s when personal computers were just becoming popular. Having the data on computer meant that the ability to analyse the data changed dramatically."

\section{Cathy Wylie, Saskatoon/Ottawa,} author, naturalist, and bander's wife. Cathy often accompanied husband Kelly and Stuart on weekend banding trips documenting an infamous Redberry Lake banding trip on a July day in 1983 - I Married a Bird Bander. ${ }^{14}$

A second article, Unparalleled service: A Tribute to Dr. C.S. Houston, details Stuart's contributions to Saskatchewan natural history. ${ }^{3}$

Mike Blom, Saskatoon/Peace River, Alberta, naturalist, master bander, forestry officer. "Stuart was the reason I started banding back in 2003. I remember going out for Ferruginous Hawks in June and Swainson's Hawks in July. We would pile into his 4Runner and go all weekend, driving muddy trails in PFRA Pastures to band as many nestlings as we could. He (is) a great mentor."

George West, Saskatoon, real estate agent. I recall: "Kindersley, Swainson's Hawk nest, a single tree in the middle of a pasture. Huge nest, $4 \mathrm{ft}$. in diameter, $50 \mathrm{mph}$ wind. I climbed the tree, made it around the nest, banded three hawks, and came down. (The banding crew) said, 'We thought the tree would break.' It was moving 6 to 8 feet in the wind; Lake Diefenbaker, Houston call(ed), a friend has a Swainson's Hawk nest to band in a coulee. Went to the beach, had to take a boat across the lake. Boating up the coulee, a huge nest is in a poplar tree. The bird glides off the nest; IT'S A GOLDEN EAGLE (7.5 ft. wing span). We can't band the young one. Don't 
have an eagle band; at Laura, Houston called, he had an owl in the turret of a barn just off the highway by Laura. I have to climb aboard. He (Stuart) said you can do it. The barn is the hip roof style. (We) put up a ladder, $24 \mathrm{ft}$., throw a ball of string over the barn, pull a climbing rope over the barn. Houston and a professor anchor the rope, I climb up the barn, walk to the turret, two owlets to band. I am banding the owls when SMACK, the female hits me from behind. My nose touches the barn roof. Lucky, I am straddling the barn roof. She comes back twice. Fortunate not to be knocked off the roof; a Houston Tree - towards the end of the day Stuart was moving slower. We were driving east on Highway 16 when I said, 'There's one in a nest.' Back we went. The nest was in a tree about $8 \mathrm{ft}$. off the ground by a train track. Houston said, 'I'll band the owlets.' We held him up so he could band the birds. That is 'A Houston Tree'; Mary would always make a lunch for the day's drive, oatmeal cookies, sandwiches; and making a run down to Outlook country, it was an ugly day - tremendous winds, and rain. We came to a nest $40 \mathrm{ft}$. up in a tall old poplar. Climbed the nest, no young. Houston said there had been birds here for years. I looked around, found two dead young that had been blown out of the nest. Damn!"

\section{Bohdan Pylypec, Yellow} Creek/Saskatoon, naturalist, wildlife researcher University of Saskatchewan. "I first met Stuart back in 1960 when he gave a talk about banding Great Horned Owls at Kinistino High School. He encouraged me to submit nest record cards notably American Goldfinches and Cedar Waxwings at Yellow Creek, and he encouraged me to submit articles to the Blue Jay as a "Young Naturalist" Weasel's Fight with a Gopher ${ }^{15}$ about my experiences at Yellow Creek. Later, I accompanied him when he banded Prairie Falcons and Golden Eagles at the Matador IBP site."

\section{The Owl-banding Song}

(To the tune of "Swinging on a Star") by David Miller

Stuart Houston is a doctor with distinguished white hair, He's witty, he's urbane, he's debonair;

Renowned for scholarship, he's known for brain, But as Mary is my witness, I'm not sure he's really sane, For every May he gives out a manic howl, And he goes off to Band the Owl.

\section{Chorus:}

One bad ankle and two bad knees Cannot keep him out of the trees, He's got a dreadful, contagious disease, That makes him want to Band the Owl.

The owl is a birdie who's got beautiful eyes

And talons to give banders a surprise;

She's pleased when you climb up to her nest of sticks, She's polite when you give bracelets to her darling chicks; She says, "I'm glad that you could come, I hope you're fine, And now I'm going to claw your face off, rotten swine!"

Chorus:

She's doing ninety-five when she hits, It could scare you out of your wits, And then she rips your shoulders to bits ... Gee but it's fun to Band the Owl!

The Bander is an acolyte to Stuart the priest, He swears he's not afraid of man nor beast.

He smiles at altitude, he laughs at pain,

He's long on adventure but he's short on brain, And when his wife says, "Stay at home Dear," he just growls,

"Don't come between me and my owls!"

\section{Chorus:}

He's got the Houston Horned Owl Disease, It makes him wanna climb up tall trees,

And let his manhood swing in the breeze,

All for the chance to Band the Owl.

\section{Chorus reprise:}

Mary's peanut butter, raisins, and bread

Seem to drive away my terror and dread, And though you think that I'm right out of my head,

I really love to band (It's hard to understand)

Their beaks are sharp, their breath is foul, Oh God, I wanna Band the Ow!! 
Kelly Koziy, Hendon/Weyburn, naturalist, sub-permittee bander, finder of 144 successful Great Horned Owl (GHOW) nests near Hendon. "As a child, I had been told of the 'Owl Doctor' who had visited the farms of both my parents and grandparents. Through the next several years, on a May weekend, Dr. Houston answered a stream of questions I had about the owls and bird banding, his crew would band the owls in nests I had found. Then for four years David Miller came in Stuart's other vehicle, more battered and with much less clearance, and he and I took turns banding. I helped with pelicans and cormorants once. When I moved to Weyburn in 1997, Dr. Houston gave me a banding sub-permit for banding GHOW again, adding Ferruginous and Cooper's Hawks, Prairie Falcons, and Golden Eagles."

\section{Gary Anweiler, Yorkton/} Edmonton, ornithologist, wildlife consultant. "My first contact with Stuart was in grade seven or eight in Melville, to join him on the Yorkton Christmas Bird Count, a short bus trip distant ... I was exhausted by the end of the day and fell asleep on the return trip. Fortunately, I awoke as the bus was leaving Melville and managed to stop it and get off in time. In May, Stuart, Bill Horseman and I banded nestling Great Horned Owls; I shinnied up to the nest and banded my first young Great Horned Owl. When I watched Stuart band at the second nest, I realized I had put my band at the previous nest ABOVE the knee, not below it as Stuart did. We at once returned to the earlier nest to re-band the owlets on the tarsus. Not an auspicious beginning. 1960 was an unprecedented irruption year for Boreal Owls (BOOW). That spring Stuart had a weekly bird program on television, and arranged for me to bring a banded BOOW to show the audience. Television had just arrived ... By now, I had spent a summer in Wisconsin with the Hamerstrom Northern Harrier research and was trained in handling raptors. The little BOOW owl, wearing appropriate jesses, flapped and perched on my hand."

Stuart received enough phone calls of BOOWs at farm sites to band 25 individuals in 1960, surpassing the total of 20 BOOWs banded by all North American banders combined to 1957. Stuart's good friend Chandler Robbins, working at the BBL, had checked the BOOW banding records and confirmed Stuart had banded more BOOW during the irruption year than the total recorded in the banding records at the BBL. ${ }^{16}$

Ron Jensen, Naicam/Saskatoon, naturalist, fisheries ecologist, hummingbird bander. "I have traveled many miles with Stuart and learned that it is entirely possible to travel Saskatchewan yet rarely drive on an asphalt highway. I have come to use the term 'Houston Highway' to describe dirt trails where a vehicle had driven that season heading in the desired direction which nearly always worked out to be a shortcut."

Stuart and Mary have banded birds in Saskatchewan for 75 and 63 years respectively. Spring migration in 2017 included the final banding of 100 juncos while 863 University Drive was being prepared for sale. Stuart held the lowest active banding license, 00460, in North America.

As a side note, the two banders with the longest North American banding records knew each other and were good friends. Stuart and Chandler Robbins finally met each other at the International Congress of Ornithology, after 20 years of corresponding. The Houston and Robbins families each occupied an entire stairwell [series of rooms] in Jesus College, University of Oxford, Oxford, England from July 24-30, 1966. Chandler S. Robbins' 76 years of banding edged Stuart by a single year. Their good friend, Chan to Mary and Stuart, Dr. C. S. Robbins Golden bird field guide series author — was 98 when he died at Laurel,
Maryland on March 20, 2017.

I thank those who gave so freely of their recollections of Stuart and Mary. Mary and Stuart who graciously read, edited, provided unpublished details, and photographs for the article. Frank Roy who critiqued and shortened the article twice, to Annie McLeod who provided the space in the Blue Jay and unknown editors who provided thoughtful comments.

1. Trembath, Sean. 2017. A History of Success: Stuart Houston stands out in Saskatchewan. Saskatoon Star-Phoenix, June 23, 2017.

2. Houston. C.S. and M.I. Houston. 1992. Banding Recoveries: A 48-Year Experience or: "It's really Mrs. Priestly's Fault". Blue Jay 50(3):182-194.

3. Wylie, C. 2014. Unparalleled service: A tribute to Dr. C. S. Houston. Saskatchewan History 66(1):14-16.

4. Houston, C.S. 1955. "Waterfowl Banding 1939-1950 by Ducks Unlimited" Oct. 1952.

Blue Jay 11(1):10.

5. Houston, C.S. 1965. Siberian Recovery of Pectoral Sandpiper. Blue Jay 23(3):121.

6. Bull, John. 1960. Season Summary. Audubon Field Notes 14:394.

7. Houston, C.S. 1965. Raptors Banded in 1964. Blue Jay 23(1):10-12.

8. Houston, C.S. 1963. Far Travels of Teal Brood. Blue Jay 21(3):101.

9. Houston, C.S., 1977. Movements of Saskatchewan-banded California Gulls. Bird-banding 48:158-161

10. Houston, C.S. and M.I. Houston. 2006. Ring-billed gulls banded in Saskatchewan, 1936-1989. Blue Jay 64(3):131-148.

11. Houston, C.S. 1974b. South American recoveries of Franklin's Gulls and Swainson's Hawks banded in Saskatchewan. Blue Jay 36:152-157.

12. Houston, C.S. 2016. Two of Saskatchewan's Oldest and Most-Studied Raptors. Blue Jay 74(3):16-18.

13. Houston, C.S. 2017. Mary Houston: North America's pre-eminent Bohemian Waxwing bander. Blue Jay 74(4):25-27.

14. Wylie, C. 1985. I married a bird bander. Blue Jay 43(1):58.

15. Pylypec, Bohdan. 1961. Weasel's fight with a gopher. Blue Jay 19(4):180.

16. Houston, C.S. 1960. 1960 - The Year of the Owls. Blue Jay 28(3):105. 